\title{
ESTIMASI STOK KARBON DI PADANG LAMUN PULAU NYAMUK DAN PULAU KEMUJAN, BALAI TAMAN NASIONAL KARIMUNJAWA, JEPARA
}

\author{
CARBON STOCK ESTIMATION AT SEAGRASS MEADOWS IN NYAMUK ISLAND \\ AND KEMUJAN ISLAND, NATIONAL MARINE RESERVE KARIMUNJAWA, JEPARA
}

\author{
Fajar Bayu Aji, Sigit Febrianto, \& Norma Afiati* \\ Program Studi Manajemen Sumberdaya Perairan, Departemen Sumberdaya Akuatik, \\ Fakultas Perikanan dan Ilmu Kelautan, Universitas Diponegoro, Semarang, 50275, Indonesia \\ *E-mail: normaafiati.na@gmail.com
}

\begin{abstract}
Blue carbon is carbon absorbed and stored as biomass in coastal ecosystems. Seagrass meadows have the primary function of storing carbon. This study aims to determine the percentage of organic carbon content in the biomass and in the seagrass sediments, as well as total carbon stock in part of the National Marine Reserve Karimunjawa.The density and coverage of seagrass were made by means of quadrat transect and carbon content analysis was performed using Loss on Ignition (LoI) method. The highest average of organic carbon content percentage on belowground biomass was $33.13 \%$, whereas from the aboveground biomass was $29.19 \%$ and in the sediment were $2.75 \%$ and $2.82 \%$ at Nyamuk Island (Station 1). Belowground biomass has higher carbon content than the aboveground, except for genus Halophila. Percentage of carbon weight in the sediment proved to be the highest contribution to the total carbon stock in seagrass meadows, i.e., 97.92-98.49\%. The highest carbon weight was also established in Nyamuk Island, i.e.,13248.29 tons C/ha. Whereas, Pokemon beach in Kemujan Island (Station 2) fixing the highest carbon stock, i.e., 83003.14 tons $C$ in its 7.68 ha seagrass area.
\end{abstract}

Keywords: biomass, carbon, Karimunjawa, seagrass, sediment

\begin{abstract}
ABSTRAK
Blue carbon adalah karbon yang diserap dan disimpan di ekosistem pesisir dalam bentuk biomassa. Padang lamun memiliki fungsi utama sebagai penyimpan karbon biru. Penelitian ini bertujuan untuk mengetahui persentase karbon organik biomassa dan di sedimen lamun, serta total stok karbon di sebagian BTN Karimunjawa. Kerapatan dan tutupan lamun diakses melalui transek kuadran dan analisis kandungan karbon organik dilakukan dengan metode Loss on Ignition (LoI). Kandungan karbon organik rata-rata tertinggi di ketiga stasiun berada di Pulau Nyamuk (Stasiun 1) dengan persentase dari biomassa-bawah sebesar 33,13\%, biomassa atas-sedimen $29,19 \%$ dan pada sedimen masing-masing sebesar 2,75\% dan 2,82\%. Berat karbon biomassa bawah lebih besar daripada biomassa atas kecuali pada genus Halophila. Berat karbon sedimen memiliki persentase kontribusi tertinggi terhadap total stok karbon di padang lamun yaitu 97,92-98,49\%. Stok karbon tertinggi juga berada di Pulau Nyamuk (Stasiun 1) yaitu sebesar 13248,29 ton C/ha. Pantai Pokemon Pulau Kemujan (Stasiun 2) dengan luas padang lamun 7,68 ha menambat total stok karbon paling tinggi, yakni 83003,14 ton C.
\end{abstract}

Kata kunci: biomassa, karbon, Karimunjawa, lamun, sedimen

\section{PENDAHULUAN}

Karbondioksida $\left(\mathrm{CO}_{2}\right)$ yang meningkat di bumi sejak Revolusi Industri adalah akibat dari bertambahnya emisi seiring dengan perkembangan peradaban manusia (Irawan, 2017). Dampaknya terhadap wilayah pesisir antara lain adalah pesisir menjadi semakin rentan terhadap erosi pantai maupun naiknya permukaan air laut. Adaptasi untuk daerah pesisir lebih sulit dilakukan karena terbatasnya data kapasitas adaptasi ekosistem pesisir (Lasabuda, 2013). Salah satu upaya mitigasi yang dilakukan guna mengurangi $\mathrm{CO}_{2}$ di atmosfer adalah memelihara dan mengembangkan kemampuan hu- 
tan dan lautan untuk menyerap dan menyimpan kelebihan karbon (Nellemann et al., 2009). Ekosistem pesisir yang dapat untuk menyerap dan menyimpan karbon atau disebut dengan blue carbon adalah hutan mangrove, rawa pasang surut (tidal marshes) dan padang lamun (Howard et al., 2014).

Ekosistem padang lamun memiliki kemampuan menjaga keseimbangan penyerapan karbon dioksida $\left(\mathrm{CO}_{2}\right)$ dari atmosfer dan menyimpannya dalam kapasitas yang jauh lebih besar daripada kemampuan hutan terestrial. Padang lamun mampu menyimpan 83.000 metrik ton karbon dalam setiap kilometer persegi, angka tersebut lebih tinggi dibandingkan kemampuan hutan darat menyerap karbon yaitu sekitar 30.000 metrik ton dalam setiap kilometer perseginya (Fourqurean et al., 2012). Hasil penyerapan tersebut kemudian disimpan dan dialirkan ke beberapa komponen yaitu dalam bentuk sedimen tempat tumbuh lamun dan dalam bentuk biomassa. Penyimpanan karbon terbesar dalam ekosistem lamun adalah sedimen (Howard et al., 2014). Fourqurean et al. (2012) mendukung pernyataan Kennedy et al. (2010) bahwa $\mathrm{CO}_{2}$ dari fotosintesis diubah menjadi karbon organik yang disimpan pada jaringan lamun dan meningkatkan biomassa lamun. Biomassa terbesar berada di rhizoma dan akar yang akan terdekomposisi perlahan secara anaerobik di sedimen. Hal tersebut menguatkan pendapat bahwa padang lamun merupakan autotrofik yang bertindak sebagai $\mathrm{CO}_{2}$ sink di biosfer (Duarte \& Jensen, 2017).

Wicaksono (2012) melaporkan total luas penutupan lamun di Kepulauan Karimunjawa adalah 59,94\%, yaitu dalam kategori sehat menurut Keputusan Menteri Lingkungan Hidup Nomor 200 Tahun 2004 karena luas penutupan berkisar 30-59\%. Hartati et al. (2017) mencatat bahwa di Pulau Menjangan Kecil dan Pulau Sintok Karimunjawa didapatkan 8 jenis lamun yaitu: Enhalus acoroides, Thalassia hemprichii, Cymodocea rotundata, $C$. serrulata, Halophila decipiens, $H$. minor, $H$. ovalis dan $H$. uninervis. Potensi kandungan karbon di Pulau Menjangan Kecil adalah 32,18 ton karbon/ha dan Pulau Sintok adalah 4,18 ton karbon/ha. Di pantai Prawean Jepara Septiani, et al. (2018) menemukan 5 spesies lamun, yaitu $E$. acoroides, $T$. hemprichii, $C$. serrulata, $C$. rotundata dan Halodule uninervis dengan luas padang lamun sekitar 4,98 ha. C. serrulata memiliki kerapatan tertinggi $(155,7 \mathrm{ind} / \mathrm{m} 2)$. Stok karbon di Pantai Prawean menyebar tidak merata, berkisar antara 0,104-1,973 gC/m2 dengan kepadatan karbon 0,69 ton/ha dan potensi total stok karbon sebesar 3,46 ton. Lebih lanjut Ganefiani et al. (2019) menambahkan bahwa potensi serapan karbon lamun di pelabuhan dan pantai Pancuran Karimunjawa adalah 0,50-0,73 ton karbon/ha.

Data tersebut mendasari dilaksanakannya kajian tentang kemampuan ekosistem padang lamun di pulau yang berdekatan, yaitu Pulau Nyamuk, Pantai Pokemon dan pantai Pulau Kemujan, Karimunjawa untuk menyerap dan menyimpan karbondioksida $\left(\mathrm{CO}_{2}\right)$, baik dari tegakan lamun maupun pada sedimennya.

\section{METODE PENELITIAN}

\subsection{Waktu dan Lokasi}

Penelitian dilakukan pada bulan April 2019 di Pulau Nyamuk dan pada bulan Juli 2019 di Pulau Kemujan. Penelitian ini dilakukan pada tiga stasiun sampling (Figure 1), yaitu Stasiun 1 Pulau Nyamuk (Figure 2), Stasiun 2 Pantai Pokemon dan Stasiun 3 Pulau Kemujan (Figure 3).

\subsection{Pengumpulan Data}

Alat utama untuk mengambil sedimen lamun hingga kedalaman $30 \mathrm{~cm}$ adalah sediment core dimodifikasi yang dibuat dari pipa pralon dengan diameter $5 \mathrm{~cm}$ dan panjang minimum $40 \mathrm{~cm}$. Penggaris $60 \mathrm{~cm}$ digunakan untuk mengukur tinggi kompaksi sedimen dalam core, kerapatan dan luas tutupan lamun dalam kuadran. 


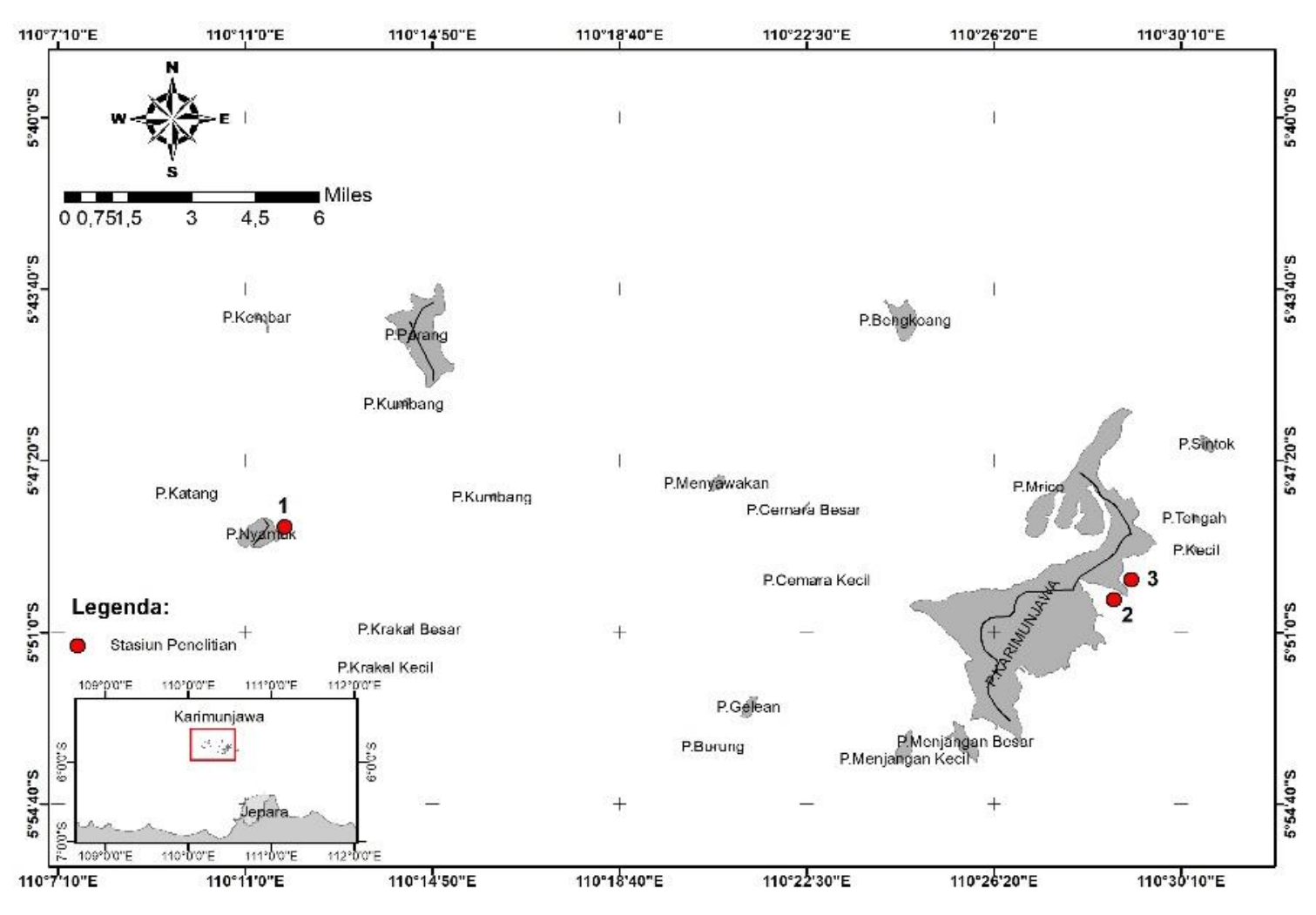

Figure 1. Seagrass sampling sites at Karimunjawa Marine Reserve, 2019 (red dots).

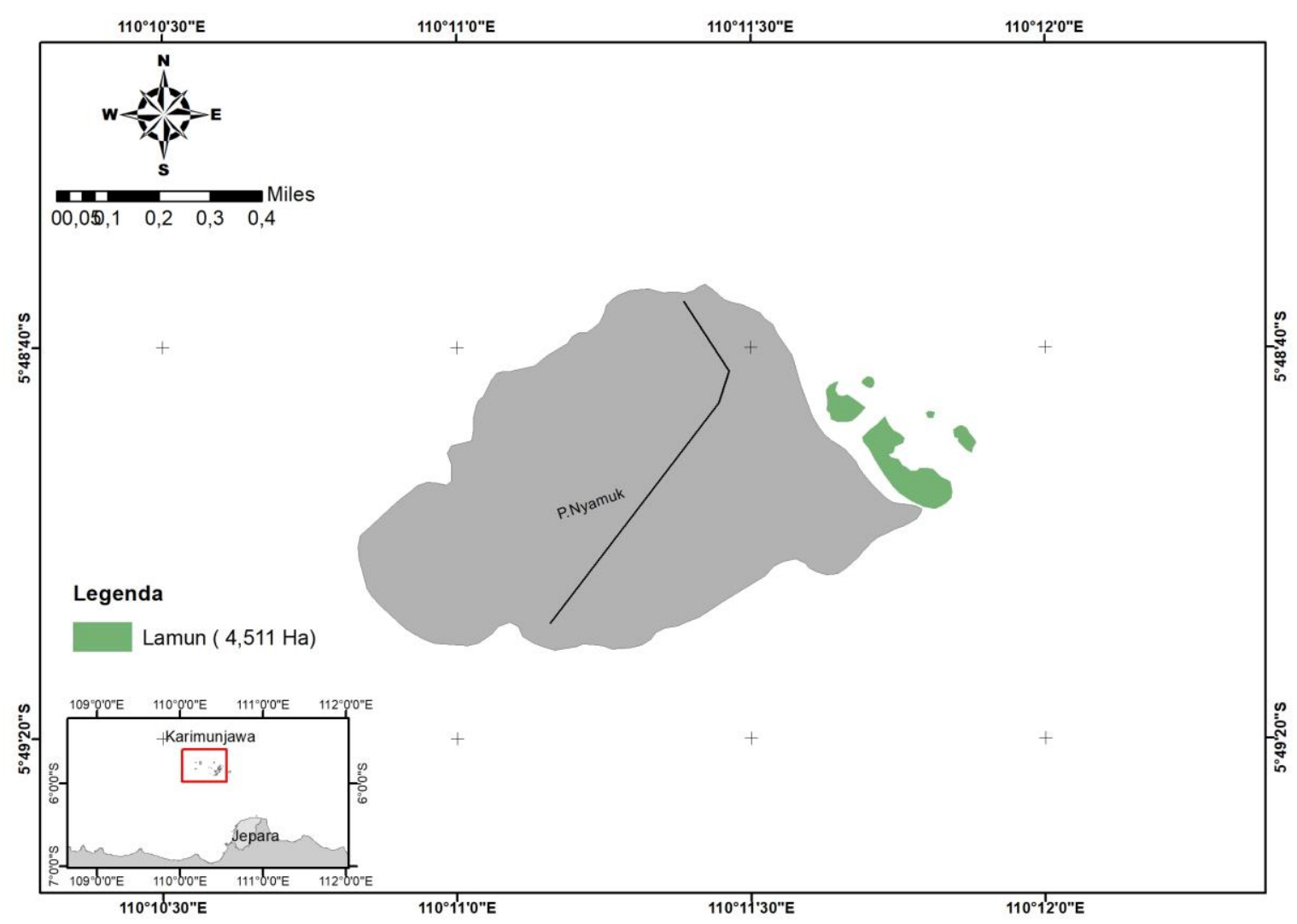

Figure 2. Seagrass coverage map at Nyamuk Island (Station 1), Karimunjawa 2019. 


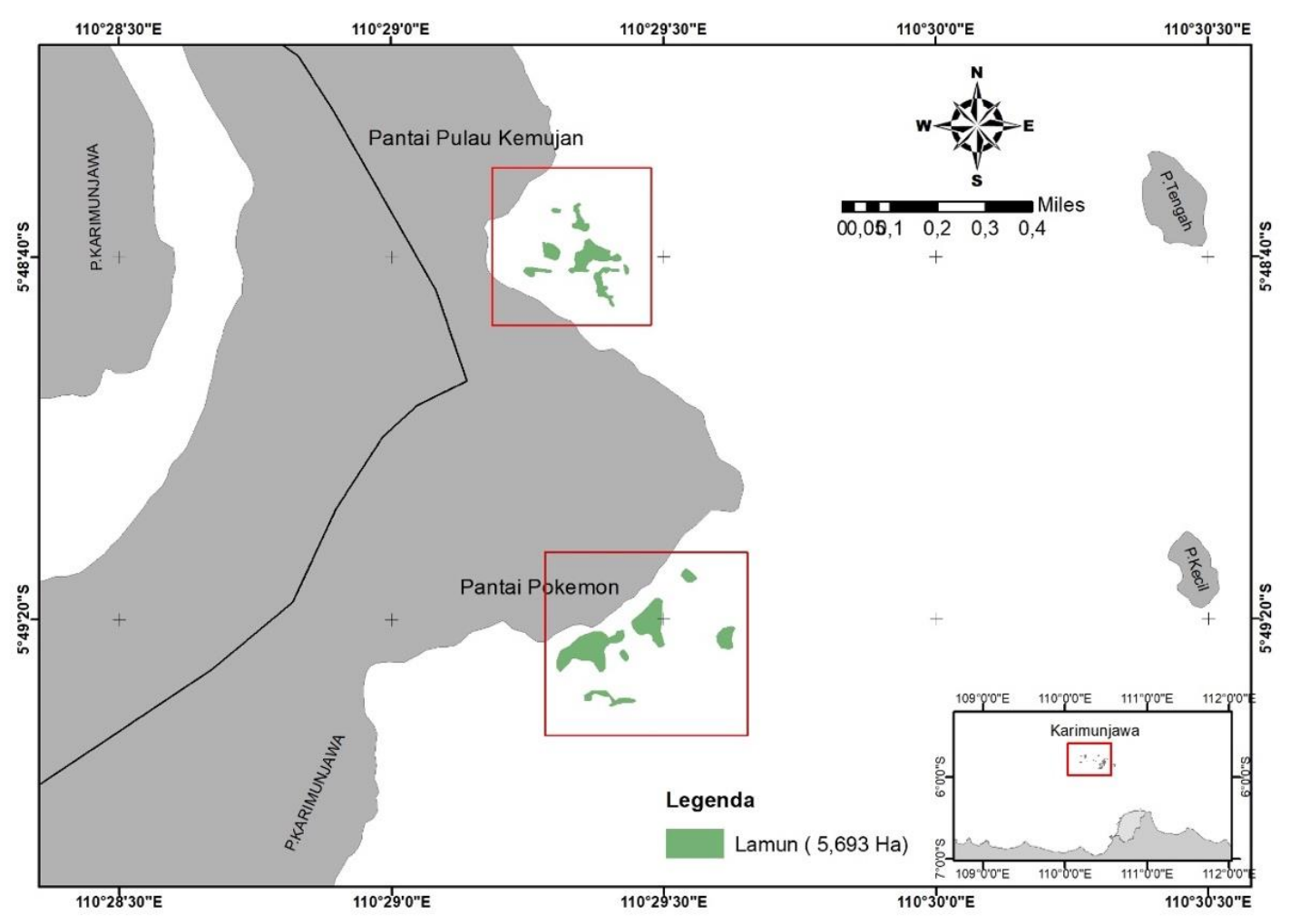

Figure 3. Seagrass coverage map of Pokemon Beach (Station 2) and Kemujan Island (Station 3), Karimunjawa 2019.

Pengambilan sampel biomassa maupun sedimen dilakukan setelah terlebih dahulu mempertimbangkan pemilihan lokasi tegakan lamun dengan jenis yang berbeda dan di sekitarnya terdapat ekosistem mangrove (purposive sampling).

\subsection{Pengolahan Citra Satelit}

Pengolahan citra satelit Landsat 8 yang digunakan untuk melakukan analisis spasial lamun meliputi komposit band dan koreksi atmosferik (TOA), penentuan area contoh lamun dan koreksi kolom air, selanjutnya dilakukan klasifikasi terbimbing (supervised classification) untuk membedakan objek lamun dan non lamun (Carpenter et al., 1996; Thornton et al., 2006).

\subsection{Pengambilan Sampel Biomassa dan Sedimen}

Titik koordinat lamun di stasiun penelitian ditetapkan melalui GPS (Global Positioning System), koordinat tersebut juga digunakan sebagai ground check terhadap digitasi luas lamun menggunakan citra Landsat. Selanjutnya, transek garis berupa roll meter ukuran $50 \mathrm{~m}$ diletakkan tegak lurus garis pantai sebagai patokan peletakan transek kuadran berukuran 50 x $50 \mathrm{~cm}$ (Seagrass Watch dalam Rustam et al., 2019). Dilakukan pendekatan nondestructive sampling dengan memperhitungkan volume dan berat sampel ketika meletakkan sediment core untuk mengambil sampel sedimen dalam tegakan lamun.

Sampel lamun dibersihkan dari semua serasah, ditimbang sebagai berat basah, dipisahkan menjadi biomassa atas (daun), biomassa bawah (akar dan rhizoma) dan sedimen, kemudian dioven pada suhu $70^{\circ} \mathrm{C}$ selama 72 jam. Selanjutnya, 1 g sampel kering oven diabukan pada suhu $450-550^{\circ} \mathrm{C}$ selama 4 jam. Timbangan analitik 2 digit digunakan untuk menimbang berat basah dan berat kering sampel lamun (Duarte, 1990). Biomassa lamun per luas $\left(\mathrm{g} / \mathrm{m}^{2}\right.$; 
Rustam et al., 2019) diperoleh dari pembagian berat kering bebas abu (g) terhadap luas core $\left(\mathrm{m}^{2}\right)$.

Secara menyeluruh kompaksi sedimen diperhitungkan dengan rumus Miyajima (2018) dalam Rustam et al. 2019; (Figure 4 dan Figure 5) sebagai berikut:

Ketebalan sedimen $=t x\left(\frac{L-b}{L-a}\right)$.

Keterangan: $t=$ tinggi sub-sampel, $L=$ panjang tabung, $a=$ tinggi permukaan sedimen dalam tabung sampai permukaan tabung, $b$ = tinggi permukaan sedimen sampai ke permukaan tabung.

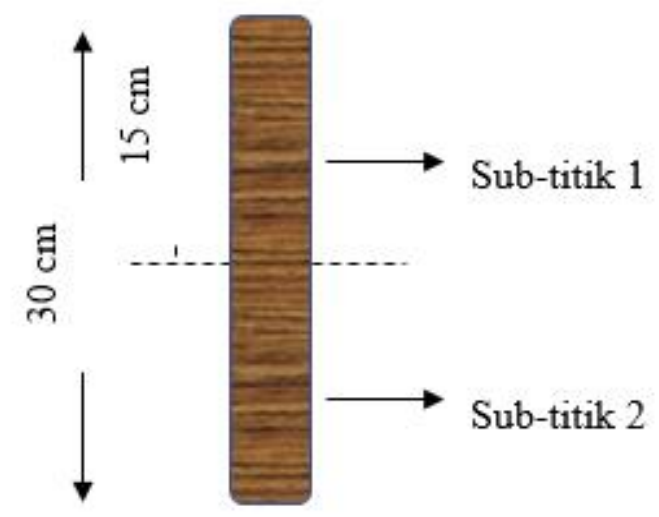

Fugure 4. Distribution of sample points.

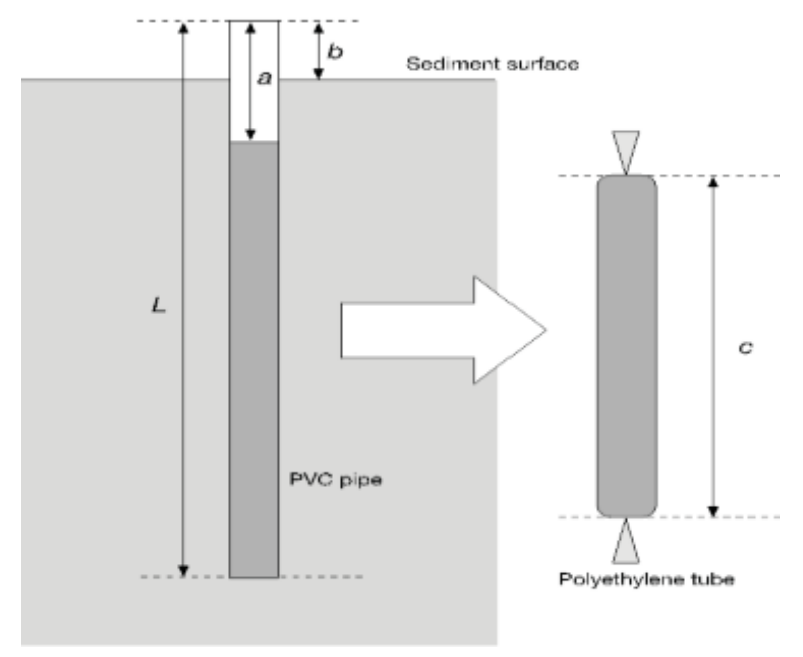

Figure 5. Sediment compaction

(Source: Miyajima, 2018 in Rustam et al., 2019).

\subsection{Analisis Data}

Bahan organik diukur menggunakan metode Loss On Ignition (LOI). Dengan perhitungan angka bahan organik merujuk pada Fourqurean et al. (2012) yaitu:

$\%$ LOI bahan organik $=\left(\frac{D-E}{D-C}\right) X 100 \%$

Keterangan: $C=$ Bobot cawan porselen kosong, $D=$ Bobot cawan porselen + sampel, $E=$ Bobot cawan porselen + sampel setelah pemijaran (residu).

Oleh karena metode LOI bukan hanya mengukur karbon organik tetapi juga bahan organik lain seperti nitrogen, sulfur dan lainnya, maka diperlukan koreksi (Fourqurean et al., 2012) sebagai berikut:

$\%$ C organik $=0,4 X \%$ LOI $-0,21$

Perhitungan kandungan karbon dalam biomassa lamun menurut Fourqurean et al. (2012):

Biomassa karbon $\left(\mathrm{kg} \mathrm{C} / \mathrm{m}^{2}\right)=$ Berat kering (kg) /luas $\left(\mathrm{m}^{2}\right) \times \% \mathrm{C}$.

Adapun perhitungan karbon pada sedimen diperlukan perhitungan dry bulk density/berat abu sedimen terlebih dahulu (Kauffman \& Donato, 2012) sebagai berikut:

Dry bulk density $=\frac{\text { berat kering sampel }(\mathrm{g})}{\text { volume sampel }\left(\mathrm{cm}^{\mathrm{s}}\right)}$.

Kandungan karbon pada sedimen lamun dihitung dengan rumus SNI 7724 (2001) tentang pengukuran dan penghitungan cadangan karbon:

$\mathrm{C}=$ Kd $x p \times \%$ C organik.

Keterangan: $C=$ kandungan karbon sedimen $(\mathrm{kg}), K d=$ kedalaman sampel sedimen $(\mathrm{cm})$, $\rho=$ berat abu $\left(\mathrm{g} / \mathrm{cm}^{3}\right), \%$ C Organik= angka persen karbon yang diperoleh dari hasil laboratorium. 
Angka hasil kandungan karbon kemudian dirata-rata sebagai angka stok karbon (Graha, 2016). Satuan yang digunakan dalam perhitungan berat karbon adalah ton $\mathrm{C} / \mathrm{ha}$. Selanjutnya total stok karbon lamun dihitung menggunakan rumus Sulaeman et al. (2005):

$$
\mathrm{Ct}=\Sigma(\operatorname{Li} x \mathrm{Ci})
$$

Keterangan: $C t=$ karbon total, $L i=$ luas padang lamun, $C i=$ rata-rata stok karbon.

Terhadap hasil perhitungan $\% \quad \mathrm{C}$ organik dan berat karbon dilakukan uji-t Independent-Samples $t$-Test dengan tingkat kepercayaan $95 \%$ untuk mengetahui perbedaan signifikan rata-rata hasil pada biomassa atas-sedimen dengan bawah-sedimen dengan hipotesis: $\mathrm{H}_{\mathrm{o}}=$ bila terdapat perbedaan yang signifikan; $\mathrm{H}_{1}=$ bila tidak terdapat perbedaan yang signifikan. Bila t hitung $<0,05$ maka $\mathrm{H}_{\mathrm{o}}$ disimpulkan diterima.

\section{HASIL DAN PEMBAHASAN}

\subsection{Keadaan Umum Lokasi}

Analisis citra satelit Landsat 8 untuk pemetaan lamun menunjukkan bahwa luas padang lamun di Pulau Nyamuk adalah 4,511 ha, di Pantai Pokemon 3.936 ha dan di Pantai Pulau Kemujan sebesar 7,684 ha. Substrat dasar perairan di dominasi oleh pasir, kerakal (Table 1).

Terdapat perbedaan jenis lamun yang ditemukan di ketiga stasiun dan masingmasing stasiun memiliki kondisi/karakteristik yang berbeda. Ketiga stasiun memiliki 6 jenis lamun. Perbedaan jenis lamun yang ditemukan berkaitan dengan kondisi lingkungan dimana lamun tersebut tumbuh. Hal ini diperkuat oleh Roelfsema et al. (2014), bahwa karakteristik nutrisi sedimen berpotensi menghasilkan variasi komposisi spesies yang berbeda-beda. Jenis lamun yang terdapat pada ketiga stasiun adalah $E$. acoroides, yang menurut Lanuru (2011) mempunyai kemampuan bertahan hidup yang tinggi.

Kerapatan jenis tertinggi dari seluruh stasiun terdapat di Pantai Pokemon Pulau Kemujan (Stasiun 2; Figure 3) yaitu $H$. uninervis yaitu 60,36 individu $/ \mathrm{m}^{2}$, akan tetapi persentase tutupan paling tinggi yaitu $23,97 \%$ adalah oleh jenis $E$. acoroides

Table 1. Characteristics of study stations in Nyamuk and Kemujan Islands, Karimunjawa.

\begin{tabular}{lccc}
\hline Characteristics & Nyamuk Island & Kemujan Island & Kemujan Island \\
& Station 1 & Station 2 & Station 3 \\
\hline Substrate & Sand, muddy sand & Sand and rubble & Coarse sand, rubble \\
and rubble & & and molusk shells \\
Mangrove stand & Present & Absent (coconut trees) & Present \\
\hline
\end{tabular}

Table 2. Density and coverage of seagrass in Nyamuk and Kemujan Islands, Karimunjawa.

\begin{tabular}{cccccccc}
\hline & & \multicolumn{2}{c}{$\begin{array}{c}\text { Nyamuk Island } \\
\text { Station 1 }\end{array}$} & \multicolumn{2}{c}{$\begin{array}{c}\text { Kemujan Island } \\
\text { Station 2 }\end{array}$} & $\begin{array}{c}\text { Kemujan Island } \\
\text { Station 3 }\end{array}$ \\
\cline { 3 - 8 } No. & Species & $\begin{array}{c}\text { Density } \\
\left(\text { ind/m } \text { m }^{2}\right)\end{array}$ & $\begin{array}{c}\text { Coverage } \\
(\%)\end{array}$ & $\begin{array}{c}\text { Density } \\
\left(\text { ind/m }{ }^{2}\right)\end{array}$ & $\begin{array}{c}\text { Coverage } \\
(\%)\end{array}$ & $\begin{array}{c}\text { Density } \\
\left(\text { ind/m }{ }^{2}\right)\end{array}$ & $\begin{array}{c}\text { Coverage } \\
(\%)\end{array}$ \\
\hline 1 & E. acoroides & 40.97 & 23.91 & 39.27 & 23.97 & 41.04 & 23.43 \\
2 & T. hemprichii & - & - & - & - & 35.13 & 6.043 \\
3 & C. rotundata & - & - & 28.73 & 5.76 & - & - \\
4 & H. uninervis & - & - & 60.36 & 12.91 & - & - \\
5 & H. ovalis & - & - & 24.36 & 1.091 & 3.13 & 0.3 \\
6 & H. minor & - & - & 2.18 & 0.12 & - & - \\
\hline
\end{tabular}


individu $/ \mathrm{m}^{2}$. Hal tersebut karena $E$. acoroides merupakan jenis lamun yang berukuran besar dibandingkan jenis lainnya. Satu individu E. acoroides memiliki angka penutupan lebih tinggi dibandingkan satu individu $H$. uninervis karena ukuran daun $E$. acoroides yang jauh lebih besar (Hartati et al., 2012).

\subsection{Persentase Kandungan Karbon Organik pada Biomassa Lamun dan Sedimen}

Rata-rata kandungan karbon organik pada biomassa bawah lebih besar daripada biomassa atas dan menunjukkan beda yang signifikan ( $\mathrm{p}<0,05$; Table 3$)$. Hal ini dinyatakan juga oleh Graha et al. (2016), bahwa secara umum kandungan karbon biomassabawah sedimen lebih tinggi dibandingkan dengan kandungan karbon biomassa-atas sedimen. Kandungan karbon rata-rata di Pantai Pokemon Pulau Kemujan (Stasiun 2; Figure 3) tidak menunjukkan perbedaan yang signifikan $(0,762>p>0,05)$, walaupun secara rata-rata kandungan karbon organik biomassabawah sedimen lebih besar (27,02\%> 26,50\%). Komposisi lima jenis lamun di Pantai Pokemon Pulau Kemujan (Stasiun 2; Figure 3) menyebabkan perbedaan yang umumnya signifikan antara biomassa bawah dan atas menjadi tidak terbukti dalam uji stastistik (Independent-Samples t-Test). Hal tersebut sama dengan pernyataan Gunawan et al. (2019) bahwa kandungan karbon antarspesies tidak menunjukkan perbedaan yang signifikan. Tegakan mangrove pada Pulau Nyamuk dan Pulau Kemujan (Stasiun 1 dan
3; Table 1) mungkin juga memberikan pengaruh terhadap perbedaan signifikan kandungan karbon (Table 3).

Rata-rata kandungan karbon organik sedimen yang tertinggi berada di Pulau Nyamuk (Stasiun 1) sebesar 2,78\%, diikuti Pulau Kemujan (Stasiun 3) sebesar 2,18\% dan pantai Pokemon (Stasiun 2) di Pulau Kemujan sebesar 1,69\%. Fourqurean et al. (2012) melaporkan karbon organik sedimen lamun sangat bervariasi, dengan angka tengah 1,8\% dan angka rata-rata global sebesar 2,5\%. Adapun Armitage \& Fourqurean (2016) menegaskan apabila lamun dengan stok karbon belowground kurang dari $100 \mathrm{~g} \mathrm{~m}^{-2}$, maka kandungan karbon organik dalam sedimen kurang dari 3\%. Menurut penelitian Lavery et al. (2013) kandungan karbon organik sedimen lamun berkisar antara 0,1-2,14\% dari berat kering dengan rata-rata 0,64 \pm $0,68 \%$. Hanya kandungan karbon organik sedimen di Stasiun 1 Pulau Nyamuk yang menunjukkan angka lebih besar dari angka rata-rata global $(>2,5 \%)$, sementara dua stasiun lain memperlihatkan hasil yang lebih rendah (<2,5\%). Kennedy et al. (2010) menyatakan karbon yang ditemukan di ekosistem blue carbon dibedakan menjadi autochthonous carbon dan allochtonous carbon. Autochthonous carbon adalah tipe karbon organik yang diproduksi dan terdekomposisi di lokasi yang sama. Allochtonous carbon adalah tipe karbon organik yang diproduksi di satu tempat dan terdekomposisi di tempat lain. Faktor hidro-oseanografi seperti gelombang, pasang surut dan arus mendistribusikan sedimen dan karbon organik dari ekosistem yang

Table 3. Organic carbon content (\%) at Nyamuk Island and Kemujan Island, Karimunjawa.

\begin{tabular}{|c|c|c|c|c|c|c|c|c|c|}
\hline \multirow{2}{*}{$\begin{array}{l}\text { Organic } \\
\text { carbon }\end{array}$} & \multicolumn{3}{|c|}{$\begin{array}{l}\text { Nyamuk Island } \\
\text { Station } 1\end{array}$} & \multicolumn{3}{|c|}{$\begin{array}{l}\text { Pokemon (Kemujan } \\
\text { Island) Station } 2\end{array}$} & \multicolumn{3}{|c|}{$\begin{array}{l}\text { Kemujan Island } \\
\text { Station } 3\end{array}$} \\
\hline & BB & BA & Sediment & BB & $\mathrm{BA}$ & Sediment & $\mathrm{BB}$ & $\mathrm{BA}$ & Sediment \\
\hline Average & 33.13 & 29.91 & 2.78 & 27.02 & 26.5 & 1.69 & 30.49 & 25.57 & 2.18 \\
\hline Deviation & 1.11 & 0.83 & 0.8 & 3.82 & 3.39 & 0.13 & 2.9 & 4.07 & 0.1 \\
\hline Significance & \multicolumn{3}{|c|}{0} & \multicolumn{2}{|c|}{0.762} & \multicolumn{4}{|c|}{0.023} \\
\hline
\end{tabular}

Information: $B B$ underground biomass (roots and rhizomes), $B A=$ aboveground biomass (leaves); significance $p<0.05$. 
berdekatan, dengan demikian memengaruhi distribusi blue carbon. Lebih lanjut Chen et al. (2017) menjelaskan karbon organik di padang lamun berasal dari berbagai sumber. Dalam penelitian ini, deposisi karbon organik di dua stasiun padang lamun yang berdekatan dengan mangrove lebih besar dibandingkan dengan stasiun padang lamun yang tidak memiliki mangrove.

Selain karena faktor keberadaan ekosistem mangrove yang berdekatan, kandungan karbon organik yang lebih tinggi di Pulau Nyamuk daripada di Pulau Kemujan kemungkinan juga berkaitan dengan jenis substrat tempat lamun tumbuh. Secara visual substrat di Pulau Nyamuk (Stasiun 1; Figure 2) berupa pasir bercampur dengan pasir-lumpur dan pecahan karang sementara di Pulau Kemujan (Stasiun 3; Figure 3) berupa pasir kasar bercampur pecahan karang (Table 1). Bahan organik pada substrat dipengaruhi oleh ukuran butir sedimen, karena butir sedimen yang lebih besar menurunkan kemampuan sedimen menyerap bahan organik. Wood (1987) dan Afiati (2007) menyatakan terdapat hubungan antara kandungan bahan organik dengan ukuran partikel sedimen, yaitu sedimen halus memiliki kandungan bahan organik yang lebih tinggi dibandingkan dengan sedimen kasar.

\subsection{Berat Karbon Biomassa Lamun}

Perhitungan berat karbon organik merupakan perkalian dari kandungan karbon organik dengan berat kering dari biomassa, sehingga berat kering menjadi faktor penting dari hasil berat karbon. Sebagaimana dilaporkan oleh Rustam et al. (2014), berat kering terbesar lamun terdapat pada bagian belowground untuk semua jenis, kecuali pada lamun jenis $H$. ovalis berat kering aboveground dan belowground memiliki angka relatif sama.

Hasil yang diperoleh di Pulau Nyamuk (Stasiun 1) menunjukkan rata-rata berat karbon biomassa bawah-sedimen sekitar 4,3 kali lebih besar dibandingkan biomassa atas-sedimen. Demikian pula di Stasiun 2 dan Stasiun 3 Pulau Kemujan, biomassa bawahsedimen masing-masing antara 3,7 kali sampai 5,5 kali lebih besar daripada biomassa atas-sedimen (Figure 6).

Hasil ini sesuai dengan penelitian Alcoverro et al. (2001) pada Posidonia, ratarata berat karbon biomassa bawah-sedimen lebih besar 3 kali lipat dari biomassa atassedimen. Lebih lanjut, Asirah et al. (2019) menyatakan tingginya simpanan biomassa bawah-sedimen berguna untuk memperkuat penancapan rhizoma lamun. Dengan demikian hal ini menjelaskan biomassa lamun

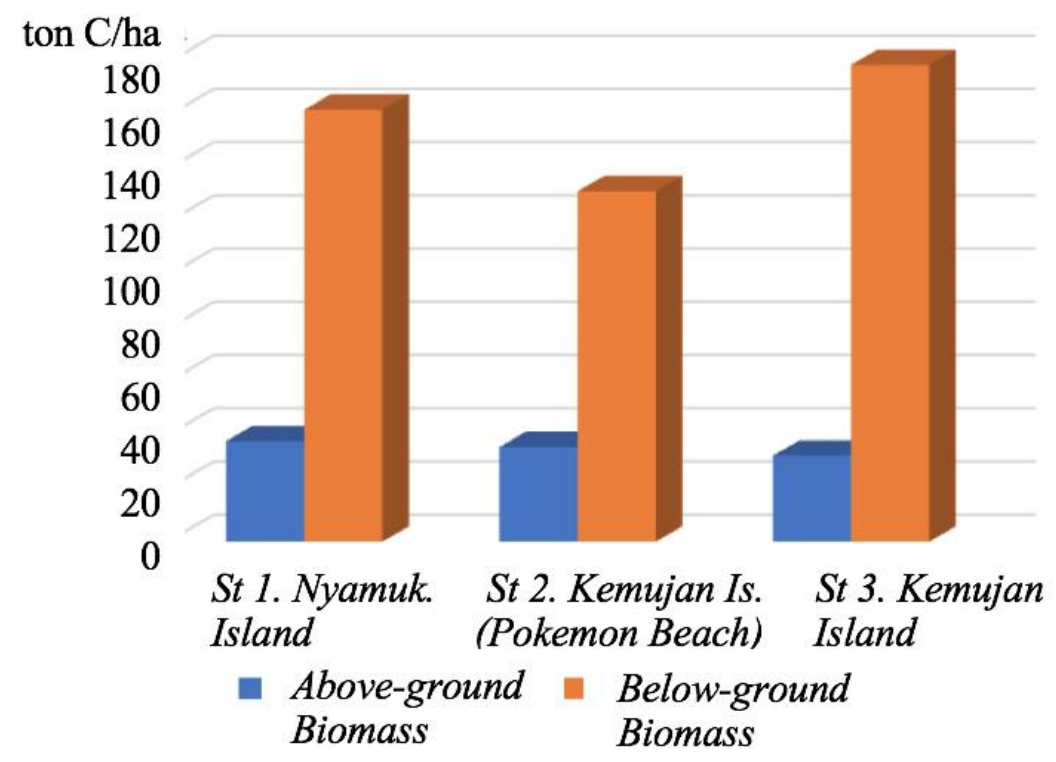

Figure 6. Carbon weight of seagrass biomass at Nyamuk and Kemujan Islands, Karimunjawa. 
yang berpotensi sebagai blue carbon lebih banyak disimpan pada bagian bawahsedimen. Materi biomassa yang terbentuk pada belowground umumnya berupa biomassa yang lebih padat (kayu) dibandingkan biomassa aboveground (daun).

\subsection{Berat Karbon Sedimen}

Rata-rata berat karbon sedimen pada Pulau Nyamuk (Stasiun 1; Figure 2) sampai Pulau Kemujan (Stasiun 3; Figure 3) secara berturut-turut menunjukkan angka 13048,14 $\pm 6698,64$ ton $\mathrm{C} / \mathrm{ha}, 10640,38 \pm 2215,54$ ton $\mathrm{C} /$ ha dan $9944,45 \pm 3462,12$ ton $\mathrm{C} / \mathrm{ha}$ (Figure 7).

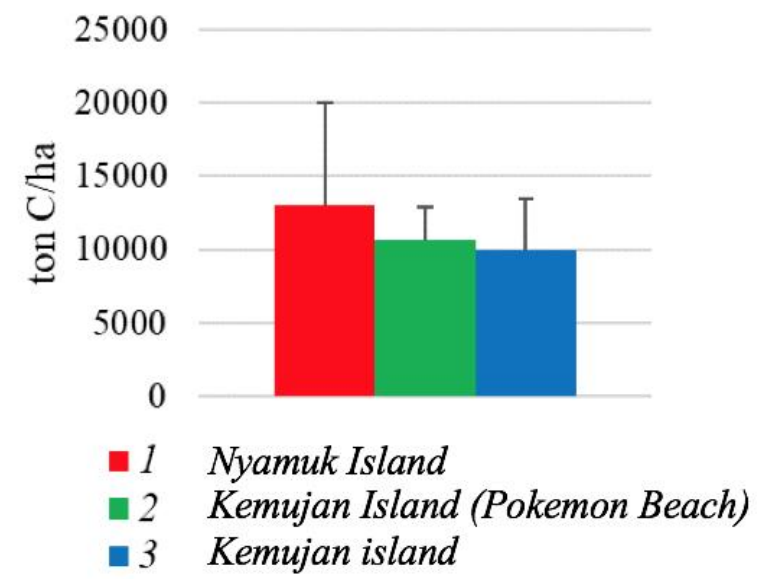

Figure 7. Carbon weight of seagrass sediment at Nyamuk and Kemujan Islands, Karimunjawa.

Indriani et al. (2017) melaporkan berat karbon sedimen lamun dalam tegakan $T$. hemprichii di Teluk Bakau sebesar 75,16, ton C/ha dan 100,06 ton C/ha di desa Pengudang, Pulau Bintan. Namun lebih lanjut, Ansari et al. (2020), melaporkan angka rata-rata stok karbon sedimen lamun Pulau Bintan yang jauh lebih tinggi, yaitu sebesar 3269 ton $\mathrm{C} / \mathrm{ha}$ di Busung dan 2400 ton C/ha di Teluk Bakau, dengan dugaan terkait jenis spesies dan kerapatan tegakan. Berikut adalah beberapa studi terdahulu yang memperlihatkan bervariasinya berat karbon organik sedimen lamun (Table 4).

Hasil penelitian ini menunjukkan bobot yang lebih besar terutama di Pulau Nyamuk (Stasiun 1) dibandingkan dengan data di Table 4. Diduga telah terjadi akumulasi dekomposisi lamun maupun serasah mangrove yang berada di sekitar Stasiun 1 . Menurut Howard et al. (2014) karbon sedimen didominasi oleh dekomposisi dari biomassa hidup seperti akar, rhizoma dan daun sehingga menjadikan sedimen sebagai tempat penyimpanan karbon terbesar di ekosistem.

\subsection{Total Stok Karbon}

Kontribusi biomassa lamun terhadap total stok karbon berkisar antara 1,51-2,08\%. Hasil ini sangat kecil jika dibandingkan dengan karbon sedimen (Figure 8). Hasil tersebut juga dibedakan antara biomassa atassedimen $(0,29-0,33 \%)$ dan biomassa bawahsedimen $(1,22-1,76 \%)$.

Jika dalam biomassa lamun dilakukan perbandingan antara berat biomassa bawah dan biomassa atas, maka biomassa bawah mempunyai kontribusi sebesar $78-84 \%$ terhadap stok karbon yang berasal dari biomassa. Hartati et al. (2012) melaporkan total stok karbon biomassa lamun di Pulau Menjangan Kecil adalah 32,19 ton dengan

Table 4. Carbon weight data comparation of seagrass sediment from several locations.

\begin{tabular}{|c|c|c|c|c|}
\hline Location & $\begin{array}{l}\text { Depth } \\
(m)\end{array}$ & $\begin{array}{c}C_{\text {org }} \text { Sediment } \\
\text { (ton C/ha) }\end{array}$ & $\begin{array}{c}\text { Average } \pm S D \\
(\text { ton } C / h a)\end{array}$ & References \\
\hline Global & 1.0 & $115.3-829.2$ & $329.5 \pm 55.9$ & Fourqurean et al. (2012) \\
\hline $\begin{array}{l}\text { East and } \\
\text { Southeast Asia }\end{array}$ & 0.3 & $38-120$ & $72.4 \pm 22.0$ & Miyajima et al. (2015) \\
\hline Abu Dhabi & 0.4 & $1.9-109.0$ & $49.1 \pm 7.0$ & Campbel et al. (2015) \\
\hline Tanjung Lesung & $0.1-0.3$ & 89.07-171.72 & - & Rustam et al. (2014) \\
\hline
\end{tabular}




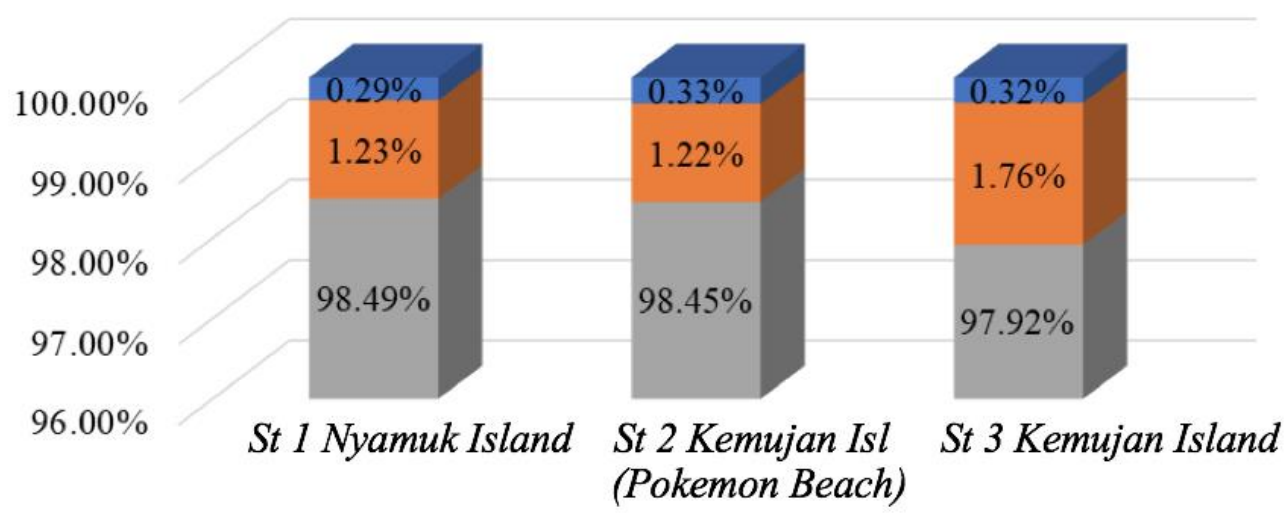

Sediment $=\begin{aligned} & \text { Above-ground } \\ & \text { Biomass }\end{aligned}$

- Below-ground Biomass

Figure 8. Percentage of seagrass carbon stock in Nyamuk and Kemunjan Islands, Karimunjawa.

stok karbon biomassa atas-sedimen sebesar 44\% dan biomassa bawah-sedimen sebesar $56 \%$. Total stok karbon di Pulau Sintok sebesar 4,18 ton dengan stok karbon biomassa atas substrat sebesar $47 \%$ dan biomassa bawah substrat sebesar 53\%. Laffoley \& Grimsditch (2009) melaporkan rasio stok karbon biomassa bawah-sedimen terhadap biomassa atas-sedimen berkisar antara 0,0058,56. Lebih lanjut, Supriadi et al. (2014) menegaskan karbon belowground berkontribusi signifikan terhadap total stok karbon biomassa lamun, dengan rata-rata $76,3 \%$, atau berkisar antara 74,2-78,9\%. Aboveground karbon ratarata berkontribusi $23,7 \%$, dengan kisaran antara 21,1-25,8\%. Harimbi et al. (2019), melaporkan bahwa biomassa bawah substrat (rhizoma dan akar) berkisar antara 60-80\% dari total keseluruhan biomassa

Persentase stok karbon sedimen dalam penelitian ini (Figure 8) memberikan kontribusi tertinggi terhadap total stok karbon, yakni sebesar 97,92-98,49\% dan sisanya berada pada biomassa lamun. Duarte et al. (2013) juga menyatakan bahwa cadangan karbon pada biomassa di padang lamun menunjukkan persentase kecil dari total stok karbon yang lebih didominasi oleh karbon di dalam sedimen.

Stasiun 1 Pulau Nyamuk memiliki bobot karbon tertinggi yaitu 13248,29 ton C/ha sementara di Stasiun 3 Pulau Kemujan bobotnya terendah di antara ketiga stasiun yaitu 10155,95 ton $\mathrm{C} /$ ha (Table 5). Hal tersebut kemungkinan karena komposisi jenis lamun di Stasiun 1 didominasi oleh $E$. acoroides yang memiliki habitus besar, sehingga menghasilkan biomassa yang besar pula selain berada dekat dengan ekosistem mangrove.

Pendleton et al. (2012) melaporkan total stok karbon lamun termasuk sedimennya sebesar 140 ton C/ha. Menggunakan aplikasi EX-ACT (Ex-Ante Carbon Balance Tool versi 7) karbon yang terdapat pada lamun di stasiun penelitian ini tergolong penyerap karbon/carbon sink bukan sebagai sumber/ source carbon. Angka carbon sink yang diserap di lokasi penelitian berkisar antara 2234-26478 ton $\mathrm{CO}_{2 e q}$ /ha dan semakin menurun seiring bertambahnya usia tegakan (Aji, Febrianto \& Afiati, in preparation).

Ganefiani et al. (2019) melaporkan total stok karbon di Pelabuhan Karimunjawa sebesar 1,28 ton $\mathrm{C}$ dengan luas area lamun 2,54 ha dan di Pantai Pancuran sebesar 2,49 ton $\mathrm{C}$ dengan luas 3,39 ha. Hasil penelitian lain di pesisir Pulau Bintan menunjukkan total stok karbon sebesar 820052 ton $\mathrm{C}$ dengan luas area 2600 ha (Indriani et al., 2017), di Pulau Baranglompo, Makassar sebesar 73,86 ton C dengan luas 64,3 ha (Supriadi et al., 2014), di Pantai Sanur, Bali sebesar 66,6 ton C dengan luas 322 ha (Graha et al., 2016). Penelitian ini 
Aji et al., 2020

Table 5. Total carbon stockof seagrass in Nyamuk and Kemujan Islands, Karimunjawa 2019.

\begin{tabular}{|c|c|c|c|c|c|c|}
\hline \multirow[b]{2}{*}{ Station } & \multicolumn{4}{|c|}{ Carbon weight (ton $C / h a)$} & \multirow{2}{*}{$\begin{array}{c}\text { Seagrass } \\
\text { meadows } \\
\quad(\text { ha })\end{array}$} & \multirow{2}{*}{$\begin{array}{l}\text { Total carbon } \\
\text { stock }(\text { ton } C)\end{array}$} \\
\hline & $\begin{array}{c}\text { Upper } \\
\text { biomass }\end{array}$ & Lower biomass & Sediment & Total & & \\
\hline 1 & 37.81 & 162.33 & 13048.14 & 13248.29 & 5.11 & 67698.74 \\
\hline 2 & 35.62 & 131.70 & 10640.38 & 10807.70 & 7.68 & 83003.14 \\
\hline 3 & 32.31 & 179.18 & 9944.45 & 10155.95 & 3.94 & 40014.43 \\
\hline
\end{tabular}

menunjukkan hasil yang lebih besar dibandingkan dengan beberapa penelitian lain di Indonesia, terutama pada sedimen (Figure 8). Menurut Alongi et al. (2016), total stok karbon di Indonesia dapat lebih besar dari yang diperkirakan karena beberapa alasan. Pertama, luas area lamun di banyak pulau belum disurvei. Kedua, sebagian besar penelitian hanya berasal dari sampel permukaan sedimen. Ketiga, beberapa padang lamun di Indonesia mempunyai sedimen yang kasar.

\section{KESIMPULAN}

Stok karbon yang tersimpan pada sedimen lamun di stasiun penelitian ini, 9944,45-13048,14 ton C/ha atau berkontribusi sekitar $97,92-98,49 \%$ terhadap total stok karbon di padang lamun. Keberadaan ekosistem blue karbon lain (mangrove) dan spesies lamun tertentu memiliki pengaruh terhadap karbon yang tersimpan di padang lamun dibuktikan dengan angka stok karbon tertinggi di Pulau Nyamuk yaitu 13248,29 ton $\mathrm{C} /$ ha. Padang lamun dengan luas tertinggi menghasilkan total stok tertinggi yaitu 83003,14 ton $\mathrm{C}$ dengan luas 7,68 ha. Dibuktikan bahwa tegakan lamun di lokasi penelitian adalah penyerap karbon/carbon sink bukan penghasil karbon/carbon source.

\section{UCAPAN TERIMA KASIH}

Para penulis mengucapkan terima kasih yang tulus kepada Kantor BTN Karimunjawa atas ijin yang diberikan dan kepada seluruh pihak yang telah membantu proses penyusunan, memberikan semangat, kritik dan saran untuk selesainya penelitian ini. Ucapan terimakasih juga ditujukan kepada para reviewer yang menyempurnakan penulisan manuskrip hingga diterbitkan.

\section{DAFTAR PUSTAKA}

Afiati, N. 2007. Ecological aspects of epiphytes on the seagrass (Thalassia sp.) of Jepara, Central Java. TORANI, (17)1: 33-42.

Alcoverro, T., M. Manzarena, \& J. Romero. 2001. Annual metabolic carbon balance of the seagrass Posidonia oceanica: The importantance of carbohydrate reserves. Marine Ecology Progress Series, 211: 105116. http://doi.org/10.3354/meps211105

Alongi, D.M., D. Murdiyaso, J.W. Fourqurean, J.B. Kauffman, A. Hutahean, S. Crooks, C.E. Lovelock, J. Howard, D. Herr, M.Fortes, E. Pidgeon, \& T. Wagey. 2016. Indonesia's blue carbon: A globally significant and vulnerable sink for seagrass and mangrove carbon. Wetland Ecol Manage, 24: 3-13. https://doi.org/10.1007/s11273-0159446-y

Ansari, R.A., T. Apriadi, \& A.D. Syakti. 2020. Stok karbon lamun Thallasia hemprichii dan sedimen Pulau Bintan Kepulauan Riau. J. Ruaya: J. Penelitian dan Kajian Ilmu Perikanan dan Kelautan, 8(1): 32-37. http://doi.org/10.29406/jr.v8i1.1478

Armitage, A.R. \& J.W. Fourqurean. 2016. Carbon storage in seagrass soils: long-term nutrient history exceeds 
the effect of near-term nutrient enrichment. Biogeosciences, 13: 313212.

https://doi.org/10.5194/bg-13-3132016

Asirah, N., C. Rani, \& M. Lanuru. 2019. Pengaruh keterbukaan gelombang dan zona pasang surut terhadap biomassa lamun di Perairan Pulau Barrangcaddi. Universitas Hassanudin Makassar. Prosiding Simposium Nasional Kelautan dan Perikanan VI. 279-288 pp.

Badan Standar Nasional (SNI 7724). 2011. Pengukuran dan perhitungan cadangan karbon-pengukuran lapangan untuk penaksiran cadangan karbon hutan (ground based forest carbon accounting). Badan Standar Nasional. Jakarta. 16 p.

Campbell, J.E., E.A. Lacey, R.A. Decker, S. Crocks, \& J.W. Fourqurean. 2015. Carbon storage in seagrass beds in Abu Dhabi, United Arab Emirates. Estuaries and Coasts, 38: 242-251. https://doi.org/10.1007/s12237-0149802-9

Carpenter, G.A., M.N. Gjaja, S. Gopal, \& C.E. Woodcock. 1996. ART neural networks for remote sensing: vegetation classification from Landsat TM and terrain data. Geoscienceand Remote Sensing Symposium, 1996. IGARSS '96. 'Remote Sensing for a Sustainable Future', International vol. 521, 529$531 \mathrm{pp}$.

Chen, G., M.H. Azkab, G.L. Chmura, S. Chen, P. Sastrosuwondo, Z. Ma, I.W.E. Dharmawan, X. Yin, \& B. Chen. 2017. Mangroves as a major source of soil carbon storage in adjacent seagrass meadows. Scientific Reports, 7: 42406:1-10. http://doi.org/10.1038/srep42406

Duarte, C.M. 1990. Seagrass nutrient content. Marine Ecology Progress, Series, 67: 201-207. https://doi.org/10.3354/meps067201

Duarte, C.M., N. Marbà, E., Gacia, J. W. Fourqurean, J. Beggins, C. Barrón, \& E.T. Apostolaki. 2010. Seagrass community metabolism: Assessing the carbon sink capacity of seagrass meadow. Global Biogeochemical Cycles, 24(4): 1-8. https://doi.org/10.1029/2010GB0037 93

Duarte, C.M., H. Kennedy, N. Marba, \& I. Hendriks. 2013. Assessing the capacity of seagrass meadows for carbon burial: Current limitations and future strategies. Ocean and Costal Management, 83: 32-38. https://doi.org/10.1016/j.ocecoaman. 2011.09.001

Duarte, C.M \& D.K. Jensen. 2017. Export of seagrass meadows contribution to marine carbon sequestration. Frontiers in Marine Science, 4(13): 1-7.

https://doi.org/10.3389/fmars.2017.0 0013

Fourqurean, J.W., C.M. Duarte, H. Kennedy, N. Marba, M. Holmer, M.A. Mateo, E. Apostolaki, G.A. Kendrick, D. Krause-Jensen, K.J. McGlathery, \& O. Serrano. 2012. Seagrass ecosystems as a globally significant carbon stock. Nature Geoscience, 5: 505-509. https://doi.org/10.1038/ngeo1477

Ganefiani, A.S. Suryanti, \& N. Latifah. 2019. Potensi padang lamun sebagai penyerap karbon di Perairan Pulau Karimunjawa, Taman Nasional Karimunjawa. Saintek Perikanan: Indonesian J. of Fisheries Science and Technology, 14(2): 115-122. https://doi.org/10.14710/ijfst.14.2.11 5-122

Graha, Y.I., I.W. Arthana, \& I.W.G.A Karang. 2016. Simpanan karbon padang lamun di kawasan Pantai Sanur, Kota Denpasar. Ecotrophic, 10(1): 46-53. 
https://doi.org/10.24843/EJES.2016. v10.i01.p08

Gunawan, J.V., M. Parengkuan, A.J. Wahyudi, \& F. Zulpikar. 2019. Estimasi stok karbon pada biomassa lamun di Pulau Semak Daun, Kepulauan Seribu. Oseanologi dan Limnologi di Indonesia, 4(2): 89-99. http://doi.org/10.14203/oldi.2019.v4i 2.229

Harimbi, K.A., N. Taufiq-Spj, \& I. Riniatsih. 2019. Potensi penyimpanan karbon pada lamun spesies Enhalus acoroides dan Cymodocea serrulata di Perairan Jepara. Buletin Oseanografi Marina, 8(2): 109-115. http://doi.org/10.14710/buloma.v8i2. 23657

Hartati, R., A. Djunaidi, Haryadi, \& Mujiyanto. 2012. Struktur komunitas padang lamun di Perairan Pulau Kumbang, Kepulauan Karimunjawa. J. Ilmu Kelautan 17(4): 217-225. https://ejournal.undip.ac.id/index.php /ijms/article/download/5136/4660

Hartati, R., I. Pratikno, \& T.N. Pratiwi. 2017. Biomassa dan estimasi simpanan karbon pada ekosistem padang lamun di Pulau Menjangan Kecil dan Pulau Sintok, Kepulauan Karimunjawa. Buletin Oseanografi Marina, VI(1): 74-81. https://doi.org/10.14710/buloma.v6i1 .15746

Howard, J., S. Hoyt, K. Isesnsee, E. Pidgeon, \& M. Telszewski. 2014. Coastal blue carbon: Methods for assessing carbon stocks and emissions factors in mangroves, tidal salt marshes, and seagrasses. Conservation International, Intergovernmental Oceanographic Commission of UNESCO, International Union for Conservation of Nature. Arlington, Virginia, USA. $180 \mathrm{p}$.

Indriani, A.J., Wahyudi, \& D. Yona. 2017. Cadangan karbon di area padang lamun pesisir Pulau Bintan, Kepulaun Riau. Oseanologi dan Limnologi Indonesia, 2(3): 1-11. http://doi.org/10.14203/oldi.2017.v2i 3.99

Irawan, A. 2017. Potensi Cadangan dan serapan karbon oleh padang lamun di Bagian Utara dan Timur Pulau Bintan. Oseanologi dan Limnologi di Indonesia, 2(3): 35-48.

http://doi.org/10.14203/oldi.2017.v2i 3.158

Kauffman, J.B. \& D.C. Donato. 2012. Protocols for the measurement, monitoring and reporting of structure, biomass and carbon stocks in mangrove forests. Working Paper 86. CIFOR, Bogor, Indonesia. 40 p.

Kennedy, H., J. Beggins, C.M. Duarte, J.W. Fourqurean, M. Holmer, N. Marba, \& J.J. Middelburg. 2010. Seagrass sediment as a global carbon sink: Isotropic constraints. Global Biogeochemical Cycles, 24: 1-8. https://doi.org/10.1029/2010GB0038 48

Laffoley, D. \& G. Grimsditch. 2009. The Management of natural coastal carbon sinks. IUCN. Gland, Switzerland. $53 \mathrm{p}$.

Lanuru, M. 2011. Bottom sediment characteristics affecting the success of seagrass (Enhalus acoroides) transplantation in the westcoast of South Sulawesi (Indonesia). 3rd International Conference on Chemical, Biological and Environmental Engineering IPCBEE vol.20 (2011) p: 97-102 (C) (2011) IACSIT Press, Singapore.

Lasabuda, R. 2013. Pembangunan wilayah pesisir dan lautan dalam perspektif Negara Kepulauan Republik Indonesia. J. Ilmiah Platax, I(2): 9210.

https://doi.org/10.35800/jip.1.2.2013. 1251 
Lavery, P.S., M.A. Mateo, O. Serrano, \& M. Rozaimi. 2013. Variability in the carbon storage of seagrass habitats and its implications for global estimates of blue carbon ecosystem device. PloS ONE, 8(9): 1-12. http://doi.org/10.1371/journal.pone.0 073748

Miyajima, T., M. Hori, M. Hamaguchi, H. Shimabukuro, H. Adachi, H. Yamano, \& M. Nakaoka. 2015. Geographic Variability in organic carbon stok and accumulation rate in sediments of East and Southeast Asian seagrass meadow. Global Biogeochemical Cycles, 29: 397-415. https://doi.org/10.1002/2014GB0049 79

Nellemann, C., E. Corcorn, C.M. Duarte, L. Valdés, C. DeYoung, L. Fonseca, \& G. Grimsditch, 2009. Blue carbon: A rapid response assessment. United Nations Environment Programme. Birkeland. 78 p.

Pendleton, L., D.C. Donato, B.C. Murray, S. Crooks,W.A. Jenkins, S. Sifleet, C. Craft, J.W. Fourqurean, J.B. Kauffman, N. Marbà, P. Megonigal, E. Pidgeon, D. Herr, D. Gordon, \& A. Baldera. 2012. Estimating global "Blue Carbon" emissions from conversion and degradation of vegetated coastal ecosystems. PloS ONE, 7(9): 1-7.

http://doi.org/10.1371/journal.pone.0 043542

Roelfsema, C.M., M. Lyons, E.M. Kovacs, P. Maxwell, M.I. Saunders, J.S. Villareal, \& S.R. Phinn. 2014. Multitemporal mapping of seagrass cover, species and biomass: a semiautomated object based image analysis approach. Remote Sensing of Environment, 150: 172-187.

https://doi.org/10.1016/j.rse.2014.05. 001

Rustam, A., T.L. Kepel, R.N. Afiati, H.L. Salim, M. Astrid, A. Daulat, P.
Mangindaan, N. Sudirman, Y. Puspitaningsih, D. Dwiyanti, \& A. Hutahean. 2014. Peran ekosistem lamun sebagai blue carbon dalam mitigasi perubahan iklim, studi kasus Tanjung Lesung, Banten. J. Segara, 10(2): 107-117. http://doi.org/10.15578/segara.v10i2. 20

Rustam, A, N.S. Adi, A. Daulat, W. Kiswara, D.S. Yusup, \& R.A. Rappe. 2019. Pedoman pengukuran karbon di ekosistem padang lamun. ITB Press. Bandung. 90 p.

Septiani, E.F., A. Ghofar, \& S. Febrianto. 2018. Pemetaan karbon di padang lamun Pantai Prawean Bandengan Jepara. Majalah Ilmiah Globe. 20(2): 117-124.

http://doi.org/10.24895/MIG.2018.20 $-2.827$

Sulaeman, Suprapto, \& Eviati. 2005. Petunjuk teknis analisis tanah, tanaman, air dan pupuk. Balai Penelitian Tanah. Badan Penelitian dan Pengembangan Pertanian, Departemen Pertanian. Bogor. 136 p.

Supriadi, R.F. Kaswadji, D.G. Bengen, \& M. Hutomo. 2014. Carbon stock of seagrass community in Barranglompo Island, Makassar. J. Ilmu Kelautan, 19(1): 1-10. https://doi.org/10.14710/ik.ijms.19.1. 1-10.

Thornton, M.W., P.M. Atkinson, \& D.A. Holland. 2006. Sub-pixel mapping of rural land cover objects from fine spatial resolution satellite sensor imagery using superresolution pixelswapping. Int. J. Remote Sens., 27, 473-491.

https://doi.org/10.1080/01431160500 207088

Wicaksono, S.G., Widianingsih, \& S.T. Hartati. 2012. Struktur vegetasi dan kerapatan jenis lamun di Perairan Kepulauan Karimunjawa Kabupaten Jepara. J. of Marine Research, 1(2): 
$1-7$.

Received : 5 November 2020

https://doi.org/10.14710/jmr.v1i2.20

Reviewed :9 November 2020

16

Accepted :18 December 2020

Wood, E.M. 1987. Subtidal ecology.

Edward Arnold. London. 125 p. 
